\title{
Synthesis of Copolymers of Furandicarboxylic Acid, Ethylene Glycol, and Poly(Angelica Lactone)
}

\author{
Konstantin L. Kaygorodova, Valery E. Tarabanko*a,b, \\ Mikhail Yu. Chernyak ${ }^{a}$, Alexander A. Kondrasenko ${ }^{a}$, \\ Andrey A. Morozova and Nikolay V. Tarabanko ${ }^{a}$ \\ anstitute of Chemistry and Chemical Technology SB RAS, \\ Federal Research Center "Krasnoyarsk Science Center SB RAS" \\ 50/24, Akademgorodok, Krasnoyarsk, 660036, Russia \\ ${ }^{b}$ Siberian Federal University \\ 79 Svobodny, Krasnoyarsk, 660041, Russia
}

Received 21.05.2016, received in revised form 17.07.2016, accepted 04.09.2016

This work demonstrates the possibility of creating biodegradable derivatives of poly(ethylene furandicarboxylate) by modification with poly(angelica lactone) chains. Block copolymers with the content of angelica lactone 33-50 mol. \% (based on monomeric links) were obtained. Polymer yields were 60-70\%, and weight average molecular weights attained 36-45 $\mathrm{kDa}$. The results of the polymers biodegradation are presented.

Keywords: copolymers, furandicarboxylic acid, ethylene glycol, poly(angelica lactone), biodegradable polymers.

DOI: $10.17516 / 1998-2836-2016-9-3-345-352$.

(c) Siberian Federal University. All rights reserved

* Corresponding author E-mail address: veta@icct.ru 


\section{Получение сополимеров}

\section{фурандикарбоновой кислоты,}

\section{этиленгликоля и полиангеликалактона}

\section{К.Л. Кайгородов ${ }^{a}$, В.Е. Тарабанько, ${ }^{a, \sigma}$ М.Ю. Черняк ${ }^{a}$, А.А. Кондрасенко ${ }^{\text {, A.A. } \text { Морозов }^{\text {a }} \text {, Н.В. Тарабанько }}{ }^{\text {a }}$ ${ }^{a}$ Институт химии и химической технологии СО РАН Федеральный исследовательский центр «Красноярский научный иентр СО РАН» Россия, 660036, Красноярск, Академгородок, 50/24 ${ }^{6}$ Сибирский федеральный университет Россия, 660041, Красноярск, Свободный пр., 79}

Продемонстрированы возможности создания биодеградируемых модификаций полиэтиленфурандикарбоксилата путем его модификации иепями полиангеликалактона. Получены блок-сополимеры с содержанием мономерных звеньев ангеликалактона в цепи полимера 33-50 мол. \%. Выходы полимеров составляют 60-70 \%, их средневесовые молекулярные массы достигают 36-45 тыс. а.е.м. Представлены результаты биодеградации полученных полимеров.

Ключевые слова: сополимеры, фурандикарбоновая кислота, этиленгликоль, полиангеликалактон, биодеградируемые полимеры.

\section{Introduction}

Wide distribution of polymeric materials in various fields of industry and market leads to the increasing amount of waste polymers, some of which find no disposal. For this reason, imparting polymers with the ability to decompose into safe nontoxic compounds in the environment is a relevant problem. One of the ways to make a polymer biodegradable is to produce its copolymers with monomers or polymer blocks that are biodegradable themselves [1-3]. For example, renewable-feedstockderived $\alpha$-angelica lactone (2,3-dihydro-5-methylfuran-2-one) and its anionic polymerization product poly(angelica lactone)-itself a biodegradable unsaturated polyester [4]-are capable of co-polymerizing with polyesters, polyolefins, and caprolactam [5].

The molecular structure of $\alpha$-angelica lactone dictates two possible polymerization pathways (Fig. 1): the double bond opening that leads to the polyfuranone (1), and the ring opening that leads to the polyester (2).

Polyfuranone formation takes place in the presence of strong Lewis acids, or under ionizing radiation [6]. This produces oligomers with $\mathrm{n}=5-8$ and melting point $257-259 \mathrm{~K}$.

However, $\alpha$-angelica lactone polymerization via ring opening is of greater interest. This reaction proceeds in the presence of sodium hydroxide, sodium butoxide [4], stannous octanoate [7]. The products of this reaction are capable of biodegradation [5]. 


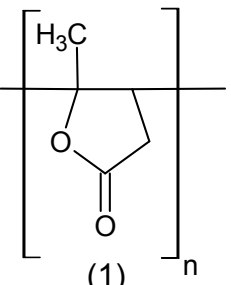

(1)

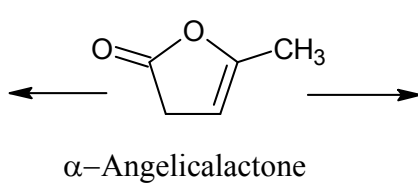

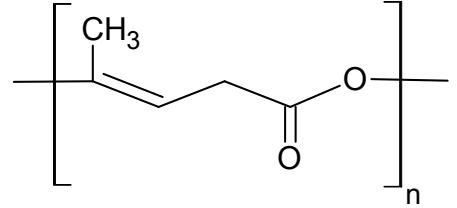

(2)

Fig. 1. Possible $\alpha$-angelica lactone polymerization pathways

The $\alpha$-angelica lactone polyester modified during polymerization with styrene has physicomechanical properties similar to those of general-purpose polystyrene, and can biodegrade in grey forest soil (Haplic Greyzem) [8].

Furan-2,5-dicarboxylic acid (FDCA) is a promising potentially versatile product obtained by oxidation of 5-hydroxymethylfurfural, itself a product of acid-catalyzed hexose carbohydrate conversion. FDCA is considered as a renewable feedstock for production of poly(ethylene furandicarboxylate)PEFDC-a polymer analogous to polyethylene terephthalate [9].

Polyethylene furandicarboxylates are quite resistant to biodegradation. However, FDCA-based polyesters are generally expected to be biodegradable [10-13]. Polymers structurally equivalent to PEFDC made with butandiol-1,4, as well as copolymers with adipic acid are more prone to biologically decompose [10]. Although if the FDCA portion of the acid component in a copolymer poly(butylene adipate - co - butylene furandicarboxylate) is $75-100 \mathrm{~mol} . \%$, then this polymer becomes impervious to destruction by porcine pancreatic lipase [10].

The goal of the present work is synthesis and comparison of properties (including biodegradability) of poly(ethylene furandicarboxylate) and its copolymers with poly(angelica lactone).

\section{Experimental}

$\alpha$-angelica lactone (98\%, Alfa Aesar), hereinafter $\alpha \mathrm{AL}$, prior to use was distilled under vacuum $(\mathrm{P}=12$ Torr, $\mathrm{T}=328 \mathrm{~K})$ with consequent fractional melt crystallization.

Furan-2,5-dicarboxylic acid was synthesized according to a method described elsewhere [14].

Poly( $\alpha$-angelica lactone), hereinafter PAL, was synthesized by anionic polymerization of aAL in the presence of sodium butoxide according to a method described earlier [4].

Molar masses and polydispersity $n=M_{w} / M_{n}$ of the obtained polymerization products were estimated by viscometry (Ostwald viscometers, capillary diameters 0.12 and $0.56 \mathrm{~mm}$, solvent-mixture of trifluoroacetic acid and 1,2-dichloroethane, 2:1 by volume) and cryoscopy (in benzophenone).

NMR spectra were recorded with a Bruker AVANCE III 600 (Centre for Collective Use, Federal Research Center "Krasnoyarsk Science Center SB RAS") at $600 \mathrm{MHz}$ operating frequency.

Synthesis of bis(2-hydroxyethyl) furan-2,5-dicarboxylate. A $250 \mathrm{ml}$ Erlenmeyer flask was loaded with ethylene glycol $(100 \mathrm{ml})$, FDCA $(5.165 \mathrm{~g}, 33.1 \mathrm{mmol})$, and hydrochloric acid $(12 \mathrm{ml}$ of $30.4 \%$ solution, $120 \mathrm{mmol}$ ). This produced a brown-colored solution.

This solution was kept at $90^{\circ} \mathrm{C}$ for 12 hours, while agitated with a magnetic stirrer. Afterwards, the solution was neutralized by sodium hydroxide (saturated solution in ethylene glycol). The excess of ethylene glycol was removed from the system by evaporation under vacuum. 
The result was a viscous deeply colored liquid that did not crystallize at room temperature. This substance was dissolved in acetone at room temperature, impurities were filtered out, and the solvent was removed by evaporation under vacuum.

White crystalline solid was isolated. Yield $70.8 \%$, m.p. $\approx 89-93{ }^{\circ} \mathrm{C} .{ }^{1} \mathrm{H}$ NMR $\left(600 \mathrm{MHz}, \mathrm{CDCl}_{3}\right)$ : $\delta 7.22(\mathrm{~s}, 2 \mathrm{H}) ; 4.32$ (t, J = 5.6 Hz, 4H ); 3.87 (t, J = 5.6 Hz, 4H); 3.08 (s, 2H).

Catalyst preparation. Air-dried powdered silicate material MCM- 41 was immersed in $0.4 \mathrm{~N}$ nitric acid solution under intense stirring for 40 minutes. Afterwards, it was filtered and rinsed until the filtrate $\mathrm{pH}$ neutrality was attained. The material was then dried at $\mathrm{T}=353 \mathrm{~K}$ until constant mass was reached.

Synthesis of diethyl furan-2,5-dicarboxylate. Stainless steel autoclave (12Kh18N10T steel, analogous to AISI 321) was loaded with anhydrous ethanol (200 ml), FDCA (3.12 g, $20 \mathrm{mmol})$, and freshly prepared MCM-41 catalyst (4 g). After sealing the autoclave, it was flushed with argon to create inert reaction environment. The autoclave was then heated to $150^{\circ} \mathrm{C}$ and kept like that for 6 hours, all with constant agitation with a magnetic stirrer $\left(\approx 900 \mathrm{~min}^{-1}\right)$. Afterwards, once the autoclave cooled down, the reaction mass was filtered and evaporated in a rotary evaporator.

Thus, $2.92 \mathrm{~g}$ of yellowish viscous liquid was isolated. It was distilled under vacuum. The principal component is diethyl furan-2,5-dicarboxylate, b.p. $170{ }^{\circ} \mathrm{C}$ (at 12 Torr). ${ }^{1} \mathrm{H}$ NMR (600 $\left.\mathrm{MHz}, \mathrm{CDCl}_{3}\right): \delta 7.17(\mathrm{~s}, 2 \mathrm{H}), 4.38(\mathrm{q}, \mathrm{J}=6.9 \mathrm{~Hz}, 4 \mathrm{H}), 1.39(\mathrm{t}, \mathrm{J}=6.7 \mathrm{~Hz}, 6 \mathrm{H})$. Yield $61 \%, 2.58 \mathrm{~g}$ isolated.

Polymerization of bis(2-hydroxyethyl) furan-2,5-dicarboxylate [15]. A $50 \mathrm{ml}$ round-bottom flask was loaded with thoroughly ground mixture of bis(2-hydroxyethyl) furan-2,5-dicarboxylate (6.50 g, $26.6 \mathrm{mmol}$ ) and antimony (III) oxide ( $65 \mathrm{mg}, 0.223 \mathrm{mmol})$.

The mixture was processed under vacuum $(\approx 2$ Torr $)$ with a magnetic stirrer agitation. First it was heated to $70{ }^{\circ} \mathrm{C}$, then heated stepwise to $260^{\circ} \mathrm{C}$ (step size $10{ }^{\circ} \mathrm{C}$, rest at each step 5-10 min), and kept at the final temperature for $30 \mathrm{~min}$. Afterwards, the system was allowed to cool down to room temperature, keeping it under vacuum in the process.

Pale yellowish-orange solid was obtained.

This product was dissolved in trifluoroacetic acid, precipitated by adding the excess of ethanol, filtered, and the product was dried under vacuum at $60{ }^{\circ} \mathrm{C}$.

Pale yellowish plastic was isolated. Yield $71.5 \%, 3.81 \mathrm{~g}$.

Copolymer synthesis. A $50 \mathrm{ml}$ round-bottom flask was loaded with diethyl furan-2,5-dicarboxylate (1.1 g, $5 \mathrm{mmol}$ ), powdered PAL (amount corresponding to a desired PAL/FDCA ratio, $\mathrm{M}_{\mathrm{w}} \approx 1200$ ), ethylene glycol $(10 \mathrm{ml})$, and antimony (III) oxide ( $65 \mathrm{mg}, 0.223 \mathrm{mmol})$.

The mixture was processed under argon atmosphere, with agitation with a magnetic stirrer. It was heated stepwise to $120^{\circ} \mathrm{C}$ (step size $10^{\circ} \mathrm{C}$, rest at each step $5 \mathrm{~min}$ ). Then, the system was evacuated to 2 Torr residual pressure, heated to $240{ }^{\circ} \mathrm{C}$, and kept this way for $30 \mathrm{~min}$. Afterwards, the system was allowed to cool down to room temperature, keeping it under vacuum in the process.

Pale yellowish-orange solid was obtained.

This product was dissolved in trifluoroacetic acid, the catalyst was filtered out, and the product was dried under vacuum at $60^{\circ} \mathrm{C}$.

Pale yellowish plastic was isolated.

${ }^{1} \mathrm{H}$ NMR (600 MHz, $\left.\mathrm{CF}_{3} \mathrm{COOH}\right): \delta 2.17,3.28,3.85,4.34,4.50,4.77,6.04,7.13,7.21,7.35$. 
Biodegradation capability study. Biodegradability of the obtained polymers was estimated under composting conditions. A sample sized $20 \times 20 \times 3 \mathrm{~mm}$ inside a stainless steel mesh casing was buried inside a compost heap comprising wetted minced plant matter, impregnated with an organomineral fertilizer solution also containing live culture of Bacillus subtilis strain 26D. Biodegradation extent was estimated by measuring the sample mass change. To do so, exhumed samples were washed with water, dried, and weighed. Afterwards, the samples were placed back into the compost for continued decomposition.

\section{Results and discussion}

Synthesis of poly(ethylene furan-2,5-dicarboxylate) (PEFDC). The polymer obtained by the polycondensation of bis(2-hydroxyethyl) furan-2,5-dicarboxylate has molecular mass $\mathrm{M}_{\mathrm{w}} \approx 34000$, which is close to earlier described products $\left(\mathrm{M}_{\mathrm{w}} \approx 44500\right.$ [15]). The polyester ${ }^{1} \mathrm{H}$ NMR spectrum includes two principal signals: furan ring protons (7.25-7.50 ppm), and alkyl protons of the ethylene glycol fragments (4.5-4.8 ppm).

Synthesis of copolymers of FDCA, PAL, and ethylene glycol. Attempts at co-polycondensation of bis(2-hydroxyethyl) furan-2,5-dicarboxylate poly(angelica lactone) according to the aforementioned method [15] did not produce copolymers. On the other hand, experiments demonstrate that co-polycondensation of diethyl furan-2,5-dicarboxylate, PAL, and ethylene glycol is possible (Fig. 2).

Table 1 represents the results of synthesizing block copolymers of PAL, FDCA, and ethylene glycol. The angelica lactone fraction in the block copolymers is 33-50 mol. \% (based on monomeric angelica lactone links, the rest being monomeric ethylene dicarboxylate links). The yield of polymers attains $60-70 \%$, their weight-average molecular weights attain 36$45 \mathrm{kDa}$.

Figure 3 demonstrates the ${ }^{1} \mathrm{H}$ NMR spectrum of a synthesized block copolymer. It includes signals from the furan ring protons (6.8-7.7 ppm), protons of ethylene glycol alkyl fragments (4.7-6.0
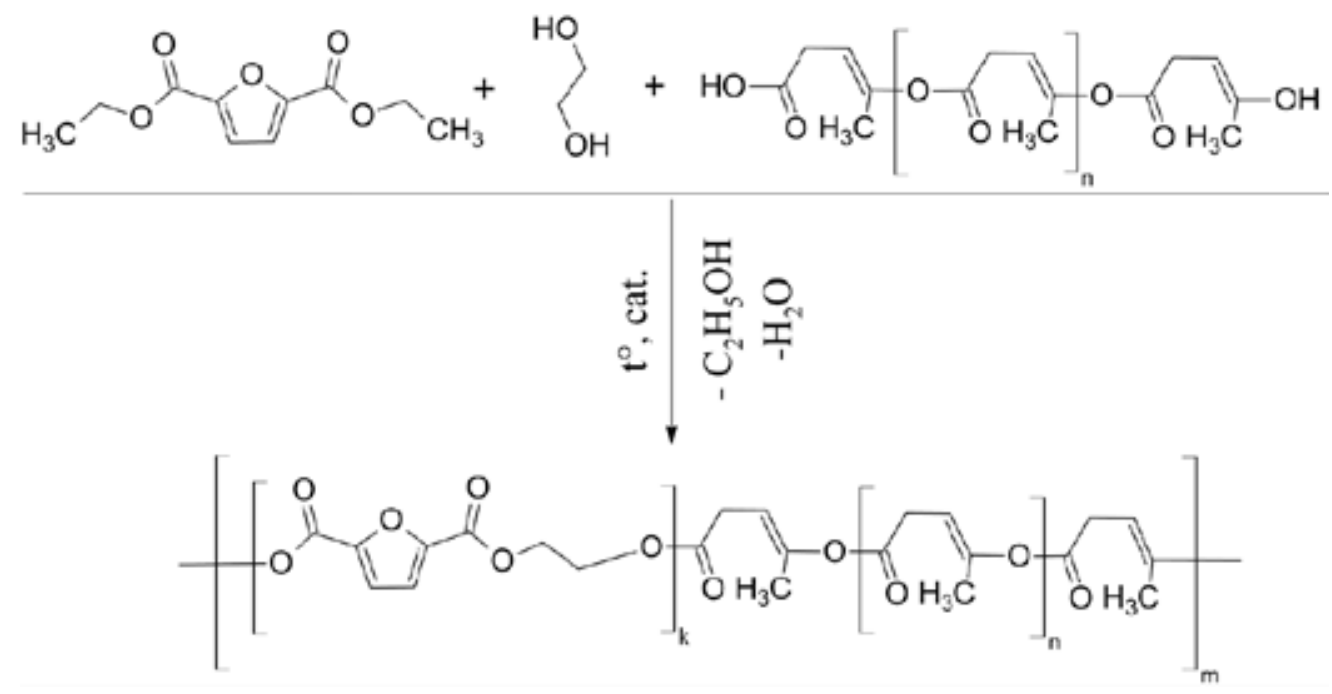

Fig. 2. Co-polymerization of diethyl furan-2,5-dicarboxylate, poly( $\alpha$-angelica lactone), and ethylene glycol

$$
-349-
$$


Table 1. PAL and PEFDC block copolymer synthesis results.

\begin{tabular}{|c|c|c|c|c|c|}
\hline \multirow{2}{*}{$\begin{array}{c}\text { Polymer } \\
\text { composition* }\end{array}$} & $\begin{array}{c}\text { Diethyl } \\
\text { furandicarboxylate, } \\
\text { mol }\end{array}$ & $\begin{array}{c}\text { Ethylene glycol, } \\
\text { mol }\end{array}$ & $\begin{array}{c}\text { PAL, mol (based } \\
\text { on monomeric } \\
\text { links) }\end{array}$ & $\begin{array}{c}\text { Yield, \% of } \\
\text { theoretical }\end{array}$ & $\mathrm{M}_{\mathrm{w}} * *$ \\
\hline $1: 1: 1$ & 0.005 & 0.005 & 0.005 & 70 & 41300 \\
\hline $4: 4: 3$ & 0.005 & 0.005 & 0.0039 & 62 & 36600 \\
\hline $2: 2: 1$ & 0.005 & 0.005 & 0.0025 & 67 & 44700 \\
\hline
\end{tabular}

* - molar ratio of FDCA : ethylene glycol : aAL in the reaction feedstock (based on monomeric links)

** - weight-average molecular weight of the polymers, viscometric determination
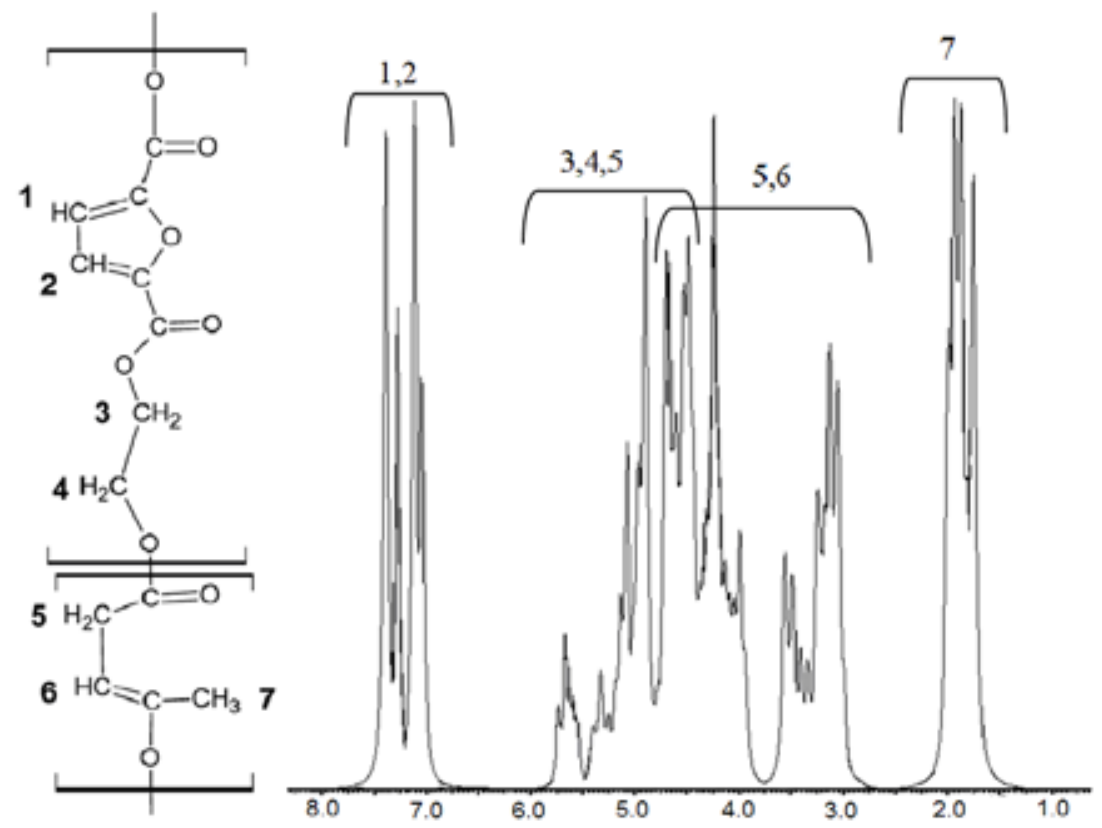

Fig. 3. ${ }^{1} \mathrm{H}$ NMR spectrum of an obtained block copolymer. The structure to the left is labeled with possible attributions of the NMR signals

ppm), and the protons of the opened angelica lactone rings: methylene and vinyl (2.7-4.7 ppm), and methyl (1.4-2.3 ppm).

Biodegradation of FDCA-based polymers. Figure 4 presents the results of the synthesized polymers biodegradation. Block copolymers with angelica lactone lose $70-80 \%$ of their mass after composting for 40-50 days.

Biodegradation rate is practically independent of the PAL content in the aAL:FDCA ratio range from 1:1 to 1:2. PEFDC that contains no poly(angelica lactone) blocks does not appreciably decompose under the studied conditions. This is consistent with earlier described stability of this polymer against biodegradation [10]. Poly(ethylene terephthalate) is also quite stable under these conditions, while its modification with small amounts of aAL and PAL results in polymers that lose $20-30 \%$ of their mass in similar destruction tests [5]. 


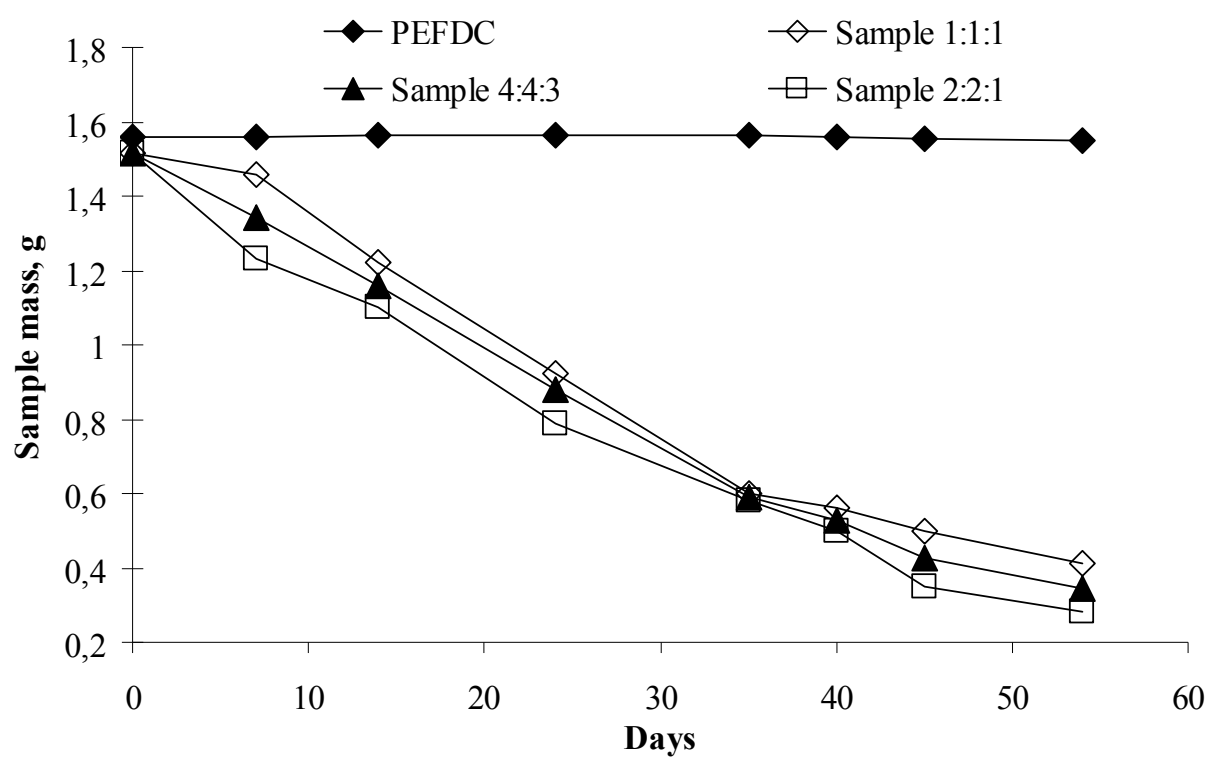

Fig. 4. Mass change of samples of poly(ethylene furan-2,5-dicarboxylate) and its copolymers in biodegradation tests by composting. Co-polymer indices represent their composition (molar ratio of FDCA : ethylene glycol : PAL in the reaction feedstock, based on monomeric links)

It can be concluded that the obtained results demonstrate the possibility of creating biodegradable derivatives of poly(ethylene furan-2,5-dicarboxylate) by modification with poly( $\alpha$-angelica lactone) chains.

\section{References}

1. Sharma S. K., Mudhoo, A., A Handbook of Applied Biopolymer Technology: Synthesis, UK: The Royal Society of Chemistry. 2011. 482 p.

2. Fomin V.A., Guzeev V.V. Biodegradable polymers, condition and prospects. Plasticheskie Massi 2001, v. 2, Р. 42-46. (In Russ.) [Фомин В.А., Гузеев В.В. Биоразлагаемые полимеры, состояние и перспективы. Пластические массы 2001. (2). С. 42-46.].

3. Polyakova E. A., Korotneva I.S., Turov B.S., Danilova A.S., Komin A.V. Biodegradable composite of starch and carboxylated latex for arts and crafts. Russian Journal of Applied Chemistry 2014, Vol. 87, Iss.7, pp 1002-1005 (In Russ.). [Полякова Е.А., Коротнева И.С., Туров Б.С., Данилова А.С., Комин А.В. Биодеградируемый композит на основе крахмала и карбоксилсодержащего латекса для декоративно-прикладного искусства. Ж. прикл. химии 2014. Т.87 (7). С. 1002-1005.].

4. Тарабанько В.Е., Кайгородов К.Л., Соколенко В.А., Черняк М.Ю. Исследование полимеризации $\alpha$-ангеликалактона. Химия растительного сырья 2006. (2). С. 37-41. [Tarabanko V.E., Kaygorodov K.L., Sokolenko V.A., Chernyak M.Yu. The study of a-angelicalactone polymerization. The chemistry of plant raw material 2006, No. 2, p. 37-41. (In Russ.)]

5. Tarabanko V.E., Kaygorodov K.L. New Environmentally Benign Polymers Produced by Copolymerization with $\alpha$-Angelicalactone. Macromolecular Symposia 2015. Vol. 354 (1), P. 367-373.

6. Marvel C.S., Levesque C.L. The Structure of Vinyl Polymers. III.1 The Polymer from a-Angelica Lactone. Journal of American Chemical Society 1939. Vol.61 (7). P. 1682-1684. 
7. Chen T., Qin Zh., Qi Y., Deng T. Degradable polymers from ring-opening polymerization of $\alpha$-angelica lactone, a five-membered unsaturated lactone. Polymer Chemistry 2011. (2). P. 1190-1194.

8. Кузнецов Б.Н., Тарабанько В.Е. Субстраты для синтеза биоразрушаемых полимеров из непищевого природного сырья. Экология и промышленность России 2010. (5). С. 52 - 54. [Kuznetsov B.N., Tarabanko V. E. The substrates for synthesis of biodegradable polymers from nonfood raw materials. Ecology and Industry of Russia 2010. Vol. 5, pp. 52-54. (In Russ.)]

9. Knoop R.J.I., Vogelzang W., van Haveren J., van Es D.S. High molecular weight poly(ethylene2,5-furanoate); critical aspects in synthesis and mechanical property determination. Journal of Polymer Science Part A: Polymer Chemistry 2013. Vol. 51 (19). P. 4191-4199.

10. Zhou W., Wang X., Yang B., Xu Yi., Zhang W., Zhang Ya., Ji J. Synthesis, physical properties and enzymatic degradation of bio-based poly(butylene adipate-co-butylene furandicarboxylate) copolyesters. Polymer Degradation and Stability 2013. Vol.98 (11). P. 2177-2183.

11. Sousa A.F., Matos M., Freire C.S.R., Silvestre A.J.D., Coelho J.F.J. New copolyesters derived from terephthalic and 2,5-furandicarboxylic acids: A step forward in the development of biobased polyesters. Polymer 2013. Vol. 54 (2). P. 513-519.

12. Patent PCT/CN2013/079767 (WO/2014/019459). Zhao D., Yang G., Biodegradable copolyester containing 2,5-furandicarboxylate, product thereof, preparation method therefor and use thereof. Publ. Date 06.02.2014.

13. Patent US8143355. Matsuda K., Matsuhisa H., Horie H., Komuro T. Polymer compound and method of synthesizing the same. Publ. Date 27.03.2012.

14. Морозов, А.А., Черняк, М.Ю., Тарабанько, В.Е., Кондрасенко, А.А. Препаративное окисление 5-гидроксиметилфурфурола азотной кислотой. Журн. Сибирского федерального университета, Химия 2014. Vol. 7 (4). C. 567-572. [Morozov A.A., Chernyak M.Yu., Tarabanko V.E., Kondrasenko A.A. Preparative 5-Hydroxymethylfurfural Oxydation by Concentrated Nitric Acid. Journal of Siberian Federal University. Chemistry 2014. Vol. 7. pp. 567-572. (In Russ.)].

15. Gomes M., Gandini A., Silvestre A.J.D., Reis . Synthesis and characterization of poly(2,5-furan dicarboxylate)s based on a variety of diols. Journal of Polymer Science Part A: Polymer Chemistry 2011.Vol. 49 (17). P. 3759-3768. 